\title{
3. India in Climate Change: The View from Tokyo
}

\author{
Yuka Kobayashi
}

This chapter first examines Indo-Japanese relations to place the relationship in a wider context, and then moves on to examine how Tokyo views New Delhi in relation to the UN Framework Convention on Climate Change (UNFCCC). It introduces the 'China prism' and 'nuclear lens', two frameworks that significantly influence Tokyo's perception of New Delhi. As a whole, the chapter argues that with regard to Japanese policy-making on climate change, India is viewed both in relation to, and in comparison with, China. India was Tokyo's preferred partner in climate change until 1998, when, following India's nuclear tests, there was a dramatic shift in Tokyo's perception of India. India was then replaced by China, as the 'better partner' for Tokyo in climate change.

\section{Indo-Japanese Relations}

India and Japan share many traits that would make them natural partners. They are two of Asia's largest democracies, and are economic powerhouses of Asia, ranked as the second and third largest economies, respectively (WTO, 2013). In energy, they are both net-importers of fossil fuels and are reliant on imports via their sea lanes of communication (SLOC). The importance of their SLOC has been re-enforced thorough the 2008 Indo-Japan Security Accord and joint exercises around the Hormuz-Malacca-Sea of Japan axis.i Given these factors, one would envision extensive ties between the two countries; however, the relationship has been a rather neglected one until the recent decade. This is due to Japan's security interests being focussed on its immediate neighbourhood. The distance between India and Japan has led to a relative neglect of Indo-Japan relations. 
Japan has traditionally enjoyed an important cultural relationship with India, one historically dating back to the latter's independence movements. While it is well known that Chinese Nationalist revolutionaries such as Sun Yatsen (resident in Japan 1895-1916) and Chiang Kaishek (resident in Japan 1905-1911) were exiled in Japan, Indian revolutionaries such as Netaji (Subhas Chandra Bose - resident in Japan 1943-1945) and Rash Behari Bose (resident in Japan 1915 until his death in 1945) similarly sought refuge in Japan. Pan-Asianism emerged as an important concept in Asia before and during WWII and, accordingly, linked India and Japan. After the end of the Tokugawa Shogunate (1868), Japan moved from the Shogunate system to a constitutional monarchy under the Meiji Emperor. Pan-Asianism became a central concept in the direction of the country under the Meiji restoration. The roots of Pan-Asianism movement in Japan can be traced back to Kakuzo Okakura's 'Ideals of the East' where he argues: 'Asia is one' (Okakura, 1904).ii Pan-Asianism was central in the writings of Okakura and India's poet laureate, Rabindranath Tagore, and it is well known that the two influenced one another. Furthermore, Japan's modernization via the Meiji Restoration, adoption of Western industrial methods, and victory in the Russo-Japanese war (1905), inspired Indian revolutionaries such as Jawaharlal Nehru.iii Thus, Japan's image in India is one of respect and admiration, lasting to this day, and is reflected in the Japanese government's surveys of the Indian population (Ministry of Foreign Affairs of Japan, 2013).iv Moreover, India's presence in Japan is felt in every household. 'Curry-rice' has become a Japanese national dish after Rash Behari Bose introduced the dish via the Nakamuraya restaurant in Tokyo. The restaurant hid the revolutionary who was being pursued during his exile in Japan. ${ }^{\mathrm{v}}$

After WWII, when Japan had lost many of its allies, India was one of the few countries to remain sympathetic. India opposed the San Francisco Peace between Japan and the Allied Powers after WWII, and signed a separate peace agreement with Japan. ${ }^{\text {vi }}$ India's sympathetic 
position is also reflected in Justice Radhabinod Pal's opposition to the Tokyo Tribunal judgement after Japan's defeat in WWII. Pal, the Indian representative on the Tokyo Tribunal, was the sole judge to oppose the judgement. India's sympathies with Japan also reach to the civilian level where India's first prime minister, Jawaharlal Nehru presented the Tokyo's Ueno Zoo with its first Indian elephant in 1949 to cheer up the Japanese children after the War (The Japan Forum, 2007). ${ }^{\text {vii }}$ The elephant was a popular addition to Ueno Zoo, and has since become a symbol of Indo-Japanese friendship. This historical background brings the two countries together and has carved a special place for Indo-Japanese relations.

\section{Tokyo's Perception of New Delhi}

In examining Indo-Japanese relations, certain frameworks of analysis can aid in the explanation of the various factors influencing this relationship. The Indo-Japan relationship can be viewed through a Realist lens where power and military capabilities take front stage. The power balance between the two countries is also influenced by their respective relationships with the major players in the region, more specifically the United States and China. The US-Japan Security Alliance places Japan under the US security umbrella, and US-India relations have also warmed considerably since the end of the Cold War, making the US matter in the context of Indo-Japanese relations. Another key player is rising China, which has a rather complicated relationship with both India and Japan due to their respective territorial disputes and historical relations. However, a Realist lens does not help explain the complex dynamics between India and Japan, particularly in a non-traditional security issue such as climate change.

Liberals would place emphasis on economic relations between India and China, evidenced in collaborative projects such as the Delhi-Mumbai Industrial Corridor project. The strong 
economic relationship between the two countries (in terms of Official Development Assistance - ODA - and Foreign Direct Investment - FDI) and the relative importance of the economic ministries in policy-making (the Ministry of Commerce and Industry in India and the Ministry of Economy, Trade and Industry in Japan) lend some weight to a Liberal emphasis. However, this framework does not capture the unique nature of the climate change issue.

Although Realist and Liberal frameworks shed some light on Indo-Japanese relations, they require supplementation through a Constructivist approach. Constructivism's focus on the role of identity — ideas, norms, and beliefs — in state behaviour is more suitable for examining climate change, a particularly emotive issue. This is firstly due to its linkage to nuclear energy, from the Japanese side, and secondly, because of the close nature of Indo-Japanese relations. This chapter examines how values and emotions can influence Japan's assessment of India in climate change. I offer two ideational frameworks, specific to the Japan-India relationship, that distil the emotive, value considerations Tokyo emphasises in its relations with New Delhi: the 'China prism' and the 'nuclear lens'.

\section{The 'China Prism' in Contemporary Indo-Japanese Relations}

Japan has traditionally seen Indian culture through the prism of 'China'. Buddhism, one of the most important religions in Japan, originally came from India via China. However, much of Buddhist thought, teaching and iconography was transformed during its travels to Japan. ${ }^{\text {viii }}$ For example, bongo, a form of writing Sanskrit that is used in Japanese Buddhism has changed in interesting ways during its translation from India to Japan via China (van Gulik, 1956). Thus, with the geographical distance between Japan and India, China served as an intermediary, with Japan absorbing these ideals indirectly, as it was transmitted through 
China. In this sense, Japan has historically absorbed aspects of Indian culture via the 'China prism'.

Although still relevant today, this prism has altered into something that, in some policy domains, focuses and defines Japan's national interest. With the rise of China, Japan views India as a partner that can counter-balance this rise, but it also means that the partnership with India is often coloured in comparison to, or in consideration with, China.

In contrast to their extensive cultural ties, political relations between India and Japan only date to the mid-nineteenth century. In 1952, India concluded a separate peace agreement with Japan following the end of WWII. Nehru refused to attend the San Francisco Peace Conference which concluded WWII, signalling that India's position was more sympathetic to Tokyo. India opposed the San Francisco Settlement since it regarded some sections to compromise Japan's sovereignty and independence (Rao, 2009).

Japan's Prime Minister, Nobusuke Kishi, visited India in 1957. Nehru’s return visit took place later that year, and Japan began its ODA to India in 1958. India relied on Japan's ODA to support its infrastructural development, with the Japan becoming the number one aid donor to India (Embassy of Japan in India, 2002). Unfortunately, this special relationship began to decline as the Cold War split India and Japan into two camps, with India leaning towards the USSR and Japan moving under the US security umbrella. This changed with the end of the Cold War and the rise of China, when India became increasingly viewed as a means for Japan to counter-balance China. Japan was the rising power in the $1980 \mathrm{~s}$, but later experienced an economic downturn, while China and India opened up their economies and achieved high annual economic development rates in the 1990s and 2000s. In this regard, Japan became a declining power, with China and India shifting to become the emerging powers central to the 
balance of power in the Asian region. Against this backdrop, Japan viewed India in comparison with China.

From the early 1990s, India practiced economic reform in order to open up its economy, and began to focus its energies on relations with Asia in its 'Look East Policy'. Japan was becoming worried about the rise of China, particularly China's modernization of the People's Liberation Army (PLA) and their motivations regarding SLOC and territorial disputes. This coincided with an increase in anti-Japanese protests in China over the Senkaku/Diaoyudao Islands. These Japanese concerns were affirmed by India who has disputed borders with China in the Indian state of Arunachal Pradesh and the region of Aksai Chin in the state of Jammu and Kashmir.

Politically and economically, India and Japan were natural partners and the post-Cold War environment brought the two even closer together. Official and economic exchange between the two countries peaked in 1997/98. For Japan, its immediate neighbourhood was no longer just the priority, thus the Ministry of International Trade and Industry (MITI) and the Ministry of Foreign Affairs (MOFA) strove to build a stronger presence in India. In the eyes of Japan, India was the better partner - a developing economy with low wages that would complement Japan's economy, without the lack of rule of law or enforcement measures, which were serious issues in China (Fujita and Hamaguchi, 2006). However, this relationship was irrevocably transformed with Pokhran II, India's nuclear tests in May 1998, which brought the nuclear issue to the forefront of the relationship. Japan has been keenly sensitive towards nuclear weapons in its international relations and has not been shy in asserting its sentiments. 
The China prism is magnified by Japan's nuclear identity. Because of Japan's experience of the attacks on Hiroshima and Nagasaki in 1945, and more recently of the nuclear disaster at Fukushima in 2011, the Japanese population holds a victimization complex with regard to nuclear weapons. ${ }^{\text {ix }}$ Furthermore, being the sole victims of nuclear weapons, there is a belief that the Japanese have a special prerogative and moral obligation to speak out on matters relating to nuclear weapons. At the policy level, this 'nuclear identity' becomes something of a lens through which matters of foreign policy can be viewed.

The nuclear issue has a significant impact on Japan-India relations. India conducted a series of nuclear tests in May 1998, testing five nuclear devices (Pokhran II). These included an atom bomb (15kt fission device), a hydrogen bomb (45kt thermonuclear device) and subkilton device (0.2 kt device), which gave India a nuclear weapons capability (Shankar Roychowdhury, cited in Swaminathan, 2003). For India, the tests were a 'prudent measure of future insurance in the military context of China's four modernizations. China must and will remain a permanent factor in our security perceptions' (Ibid.). After Pokhran II, Japan publically condemned India and also gathered support for criticism in other venues such as the UN, as I discuss later. Japan suspended all political exchanges and economic assistance with India for about three years. In this regard, the nuclear tests were unfortunately timed. They were conducted just as the Indian economy was opening up and Japan was shifting its focus beyond North East Asia to find partners further afield.

With the Japanese economy slowing down and China rising in the late 1990's, India appeared as both an alternative ally and economic opportunity. As a result, MITI and Keidanren began involvement in pushing Japan's presence in India, and by 1998 Foreign Direct Investment 
(FDI) was rising reaching its peak in 1997 with 531.5 million US dollars (Jaishankar, 2000). After a gap of over a decade where Japan-India relations were neglected, high-level visits were being conducted by MITI and SDF (Self Defence Forces of Japan) - however, this was short-lived with Pokhran II.

The then ambassador to India, Hiroshi Hirabayashi noted 'It (the test) was particularly perceived as a slap in the face by the Japanese people. To be frank, I was rudely shocked and betrayed by India, which I believe to be an anti-nuclear champion. Pokhran (II) tests chilled our relationship to a great extent' (Hirabayashi, 2002). This quote shows the intimate and highly emotive relations India had with Japan. This sense of 'betrayal' was reflected in Tokyo's actions following Pokhran II. There followed a 'freeze' in the bilateral relationship, as the Japanese government suspended political exchanges and economic assistance. Ambassador Hirabayashi was recalled back to Tokyo for consultations with Prime Minister Hashimoto. Furthermore, the Japanese Diet issued a statement that the tests were 'acts of destruction of the global environmental destruction of ecosystem of constituting a threat to the survival of human beings' (Pant, 2010). Below, I show how Pokhran II impacted on one specific domain of Indo-Japanese relations by focussing on the case study of climate change. Climate change brings together various complex issues: environmental protection, economic development, and nuclear energy, which make it a suitable case to examine the shifts in Tokyo's perception of New Delhi.

\section{Climate Change and the Japan-India Relationship}

This chapter explores how the China prism and the nuclear lens influence Japan's perception of, and behaviour towards, India in the issue area of climate change. More specifically, I examine Japan's conduct with respect to the Clean Development Mechanism (CDM), which 
has run from 2006 up to the present), and its pilot phase of Activities Implemented Jointly (AIJ), which ran from 1995 to 2006. These are both Kyoto Mechanisms that bring developed and developing countries into cooperative frameworks. A closer examination of CDM and AIJ shows how Tokyo moved to 'punish' New Delhi after Pokhran II.

Before discussing Japan's view of India in climate change, one requires an understanding of the decision-making apparatus for CDM/AIJ in Japan. Like many decision-making procedures, $\mathrm{CDM} / \mathrm{AIJ}$ is agreed through negotiations involving a complex web of government and actors in environment and energy in both the host state and in Japan. $\mathrm{CDM} / \mathrm{AIJ}$ are run by the MOFA in consultation with the UNFCCC, but the CDM/AIJ projects are more specially directed through the Kyoto Mechanism Platform, with the Ministry of Environment as the key liaison point. ${ }^{\mathrm{x}}$ The turf wars and bureaucratic structures of environmental policymaking in Japan is a complex topic, but one that will not be discussed in detail here. However, it is worth noting that decision-makers in CDM/AIJ in Japan are energy, environment and business/commerce actors with grassroots involvement. The final negotiations are conducted by MOFA, but the ideas for the projects usually come from the bottom up, with a significant degree of input from energy actors. As a result, the CDM/AIJ project ordinarily reflects the interests of energy, environment, and/or business actors first, with input from MOFA at the very end stages.

According to the total numbers of AIJ and CDM registered at the UNFCCC (Figure 1), it is apparent that China is placed ahead of India in the capacity as host country for these projects. In terms of Japanese activity in these mechanisms, three out of the five Japanese AIJs are located in China with no AIJ in India during the pilot phase, that is, up until 2006. Since the AIJ moved to the CDM phase after 2006, however, India has been able to secure some Japanese CDMs, but still lags behind China. 


\section{Total CDM activities under the UNFCCC, by host country (Total 7,430)}

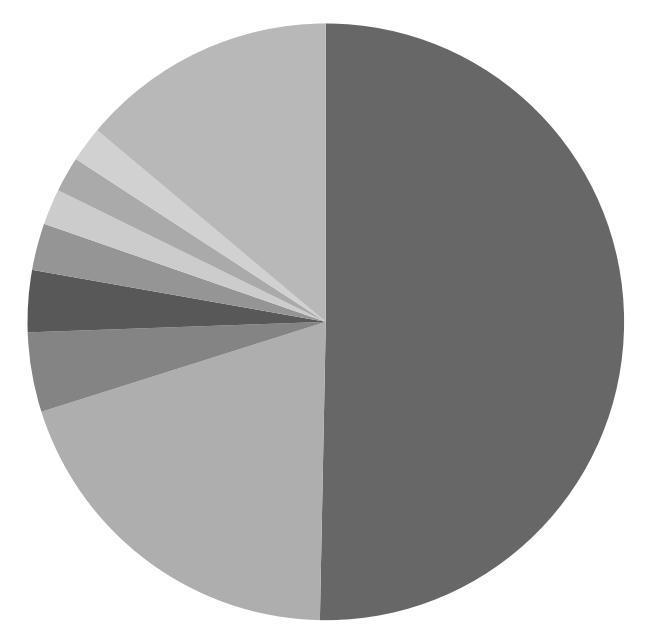

China

India

Brazil

vietnam

Mexico

Thailand

Malaysia

Indonesia

Others

Figure 1: CDMs under UNFCCC by host country (Source: UNFCCC, 2014a).

Figure 2 represents Japan's CDMs, organised by host country. What becomes obvious is that China, with 455 projects of the total 821, is the recipient of over half of Japan's CDMs. When one considers that China is the number one emitter of GHGs (23 per cent of global emissions), China's Japanese CDM numbers may not come as a surprise. However, India is the third highest emitter of GHGs (7 per cent of global total), but only has 42 of Japan's CDMs (Rogers, 2012). Both China and India are emerging powers with influence over the climate change regime. The two countries are also heavily reliant on fossil-fuels. What then explains this huge gap between Japanese CDMs in China and India? 


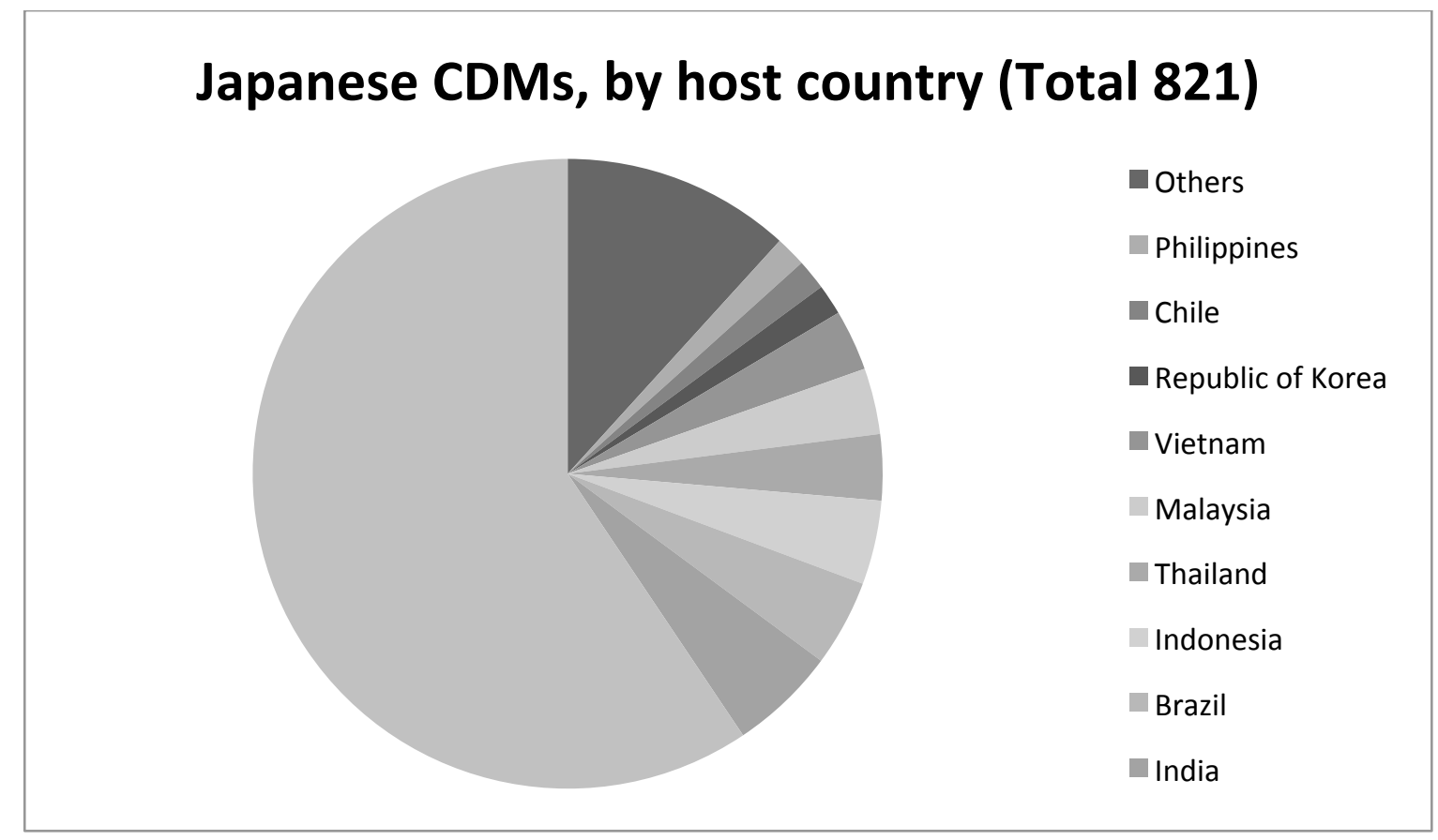

Figure 2: Japanese CDMs by host country (Source: Japan CDM Platform, 2012)

Cooperative efforts towards climate change mitigation under the UNFCCC are split between the developed (Annex I) countries and developing (non-Annex I) countries. The Annex I countries are developing countries who, under the principle of 'common but differentiated responsibility', have emissions caps. India and China are both non-Annex I countries, and do not have emissions caps under the Kyoto Protocol. The two share many similarities: both are population giants with large emissions, and their economic development relies heavily on coal. They also both harbour anti-colonial sentiments that are amplified by the UNFCCC's division between the Global North and South. At the 15th Conference of Parties (COP) to the UNFCCC in Copenhagen (2009), countries gathered together to negotiate a second stage for the 'Kyoto Protocol'. ${ }^{\text {xi }}$ According to analysts at the Conference, India, together with China, 'wrecked the negotiations' as leaders of the BASIC group of rising powers (Lynas, 2009). Thus, both countries are frequently linked through their shared image as obstructionist actors in climate change. 
Japan has been one of the leaders in the UNFCCC and takes a proactive stance on emissions cuts. Prior to Copenhagen, the Democratic Party of Japan (DPJ) raised its pledge for emissions cuts from eight per cent, a figure determined during the Liberal Democratic Party of Japan (LDP) leadership, to 25 per cent by the year 2020 from 1990 levels. ${ }^{\text {xii }}$ Considering that Japan is the sixth largest emitter of GHGs, the Japanese policy is quite ambitious and signals its resolve to combat global warming. ${ }^{\text {xiii }}$ India, on the other hand, has the second largest population in the world and is currently a medium development level country according to the UN Human Development Index (UNDP, 2014). In terms of climate change, India is the third largest emitter of greenhouse gases (GHG), and is heavily reliant on coal, one of the major causes of GHG, so the future development trajectory for the country is of concern.

Japan fought hard at the international negotiations to seek India and China's acceptance of emissions caps for the second commitment period of the Kyoto Protocol. Japan and India's prime ministers met at the Association of Southeast Asian Nations (ASEAN) Summit in 2009 to agree to work together in 'a positive and constructive' manner on the issue of climate change issue (Tuteja, 2009). Although there is mutual respect for each other's positions on climate change, the different developmental stages of India and Japan, which make the two economies complementary, also complicate cooperation on climate change mitigation. However, the CDM/AIJ bridges these kinds of differences, allowing Annex I countries (for example, Japan), to reach their emissions cuts by counting the emissions reductions of the projects that Annex I countries implement in non-Annex I countries (for example, India). Japan is one of the leading countries in climate abatement technology and one of the most active countries in the CDM/AIJ. 
Out of the non-Annex I countries available for Japan to cooperate under the CDM/AIJ, India was democratic, English-speaking and relatively transparent and was thus perceived as a 'better partner' (1995-1998). ${ }^{\text {xiv }}$ In comparison, the other big emitter in the non-Annex I group, China, was seen as autocratic, non-transparent and a difficult partner. However after India's nuclear tests in 1998, the status of India and China switched. China was then seen as the 'better partner', attracting more numbers of Japanese AIJs and CDMs than India.

Below I argue that Japan's view of India rests on two factors: the historical 'China prism', and the 'nuclear lens.' However, it is also important to note that Tokyo's perceptions are not formed in a vacuum but incorporate a range of calculations regarding the hegemonic powers of the Asia-Pacific - the US and rising China, and also in the context of economic considerations.

\section{The 'China Prism' in Indo-Japanese Cooperation on Climate Change}

According to Wataru Nishigahiro, former Deputy Chief of Mission for the Japanese Embassy in India: 'the relationship with India is important, partly because of the factor of emerging China. We are not confronting China, but we have to manage the relationship with China carefully. And in that process, our relationship with India becomes more meaningful' (Tuke, 2011). Following the end of the Cold War, the rise of China, UN reform, maritime security, counter terrorism and environment were issues that brought India and Japan together. This allowed India to be Japan's preferred partner prior to Pokhran II. There were already discussions between the security communities in India and Japan about holding joint naval exercises (the predecessors to the Malabar exercises) as early as 1997/98. However, the nuclear tests alarmed the Japanese, worsening Indo-Japanese relations, so the joint exercises were shelved until mid-2000. 
According to a MOFA official, Tokyo had perhaps 'punished India too much after Pokhran II' (Author interview, 2009). From this statement, he was referring to the lack of Japanese CDM projects in India. The CDM received a lukewarm reception when it was introduced in the 1990s, with India and China reacting particularly cautiously (Kobayashi, 2003). However, by the late 1990s, it was seen by developing countries as an effective means to absorb climate change abatement technologies, and the discussion in the South had then became one of how to 'best attract CDM projects' (Ibid.). Since China and India were the 'big two' in climate change emissions, the CDMs in these countries were seen as key to the success of the UNFCCC. However, Figures 1 and 2, above, indicate that India is very behind China and lacks 'attractive power' for CDMs. The magnitude of China's emissions may explain China's numbers to a certain extent, but India is not far behind China in terms of importance in GHG emissions. This indicates that there are factors other than GHG emissions that explain India's low CDM project numbers.

CDM projects often address energy efficiency, meaning other externalities, such as China's trans-boundary pollution, acid rain or 2.5 particulates, which are of great importance to Japan, can also be addressed. The high number of Chinese CDMs can be explained by these externalities, however, 2.5 particulates were less of an issue in the early $2000 \mathrm{~s}$. In terms of Japanese CDMs, there was a conscious decision to 'punish' India after its Pokhran II tests by not rewarding it with CDMs. The dates of the CDM projects in India indicate this is a trend with numbers gradually recovering in the mid-2000s, concurrently with an improvement of Indo-Japanese relations.

The gap between China and India's numbers of Japanese CDMs becomes clear when viewed through Japan's 'nuclear lens', as I argue below. The 'China prism' is however useful in understanding Indo-Japanese relations in the historical past, and is also relevant today, as I 
have shown. Tokyo makes its decisions on climate change vis-à-vis India in relation to its China policies, which are not unique to Japan, since China and India are both heavyweights in climate change negotiations. However, the 'China prism's' influence over decision-making in Tokyo is a factor that should be taken into consideration.

\section{The 'Nuclear lens' in Indo-Japanese Cooperation on Climate Change}

After Pokhran II, the status of India and China switched: China was then viewed as the 'better partner, attracting more numbers of Japanese AIJs and CDMs than India. Japan's view of India in climate change is assessed in reference to China.

The Pokhran II tests shocked the global community and many countries were quick to react. This impact was visible in India's relations with the US and the EU, not only with Japan. Australian and European aid was cut, but these cuts were minimal in comparison to American and Japanese aid to India. Although Japan's nuclear identity is not something that is legally binding, the US on the contrary has a domestic law - the 1994 'Glenn Amendment' - which stipulates that the US impose economic sanctions (including bilateral aid, credit and loan guarantees for US firms, and multilateral credit agencies, IMF and World bank) on any country engaging in nuclear testing (Ghosh, 1998). ${ }^{\mathrm{xv}}$ US, Japan and many European countries (excluding UK and France) suspended bilateral aid, which was equivalent to 3 billion US dollars (Ibid). In June 1998, Tokyo also refused to play host for a very important venue for discussion of Indian aid, the Aid India Consortium. No other country was willing to step in as host after Tokyo's refusal (Ibid.).

Prior to 1998, India had received an excess of 1.5 billion US dollars from Japan on an annual basis (Ghosh, 1998). After Pokhran II, there was a cutback of roughly 1 billion US dollars of Japanese bilateral aid (except for emergency, humanitarian and grassroots assistance) that 
lasted approximately three years. This also impacted future aid proposals and Tokyo backed down from hosting the India Developmental Forum. Furthermore, there was a cautious examination of technological transfer, resulting in stricter control (Jaishankar, 2000).

The official response also permeated the cultural arena with exchange between India and Japan being suspended. The Empress Michiko of Japan was due to be given the keynote speech at the International Board on Books for Young People World Congress in New Delhi in September 1998, but cancelled after Pokhran II in May 1998. Instead a recorded speech was delivered as a video message (Roy, 2013).

Japan together with the G7 and non-G7 countries opposed lending by the International Monetary Fund (IMF), World Bank (WB) and the Asian Development Bank (ADB) to India. As WB loans are spread over four to eight years; the impact of 1998 cannot be visibly traced. However, the WB postponed a decision to approve 865 million US dollars in project aid after Pokhran II (Sanger, 1998). This action was under the leadership of the Japanese, but the US and EU, who are on the board of WB board of directors, played a central role in this decision.

Japan led the G8 Summit at Birmingham in 1998 to send a clear message against India's nuclear tests. At the G8 Summit, Japan rounded up support for a statement condemning India's tests as an 'intolerable challenge to international society' (Jaishankar, 2000). Subsequently, the South Asia Task Force was setup to coordinate pressure to cease nuclear tests on India and Pakistan, and Japan took leadership of this group (Ibid.).

In the UN Security Council, Japan coordinated with Sweden, Costa Rice and Slovenia to pass UNSC Resolution 1172 which 'demanded that those countries refrain from further nuclear tests and urged them to become parties to the Treaty on the Non-Proliferation of Nuclear Weapons (NPT) and to the Comprehensive Nuclear-Test-Ban Treaty (CTBT), without delay 
and without conditions (UNSC, 1998). At the P5 foreign ministers' meeting in Geneva, Japan also issued an appeal not to grant India and Pakistan nuclear weapon state status. Although a failure, Japan in its desire to punish India also tried to induct Pakistan into the ASEAN regional forum (ARF) (Jaishankar, 2000).

As the Indian economy has been growing at a very high rate, it is difficult to assess the impact of the sanctions imposed on India after Pokhran II. However, according Morrow and Carriere, it is apparent that FDI suffered a direct impact after May 1998. This impact was also felt in the credit ratings as the condemnations of various governments had a direct influence on India's performance in these ratings (Morrow and Carriere, 1999).

The impact of Pokhran II was also visible in climate change, as I have shown above. Japan also made clear that the country's position was not negotiable for nuclear issues. After 1998, India was replaced by China as the 'better partner' for CDMs, and as a result India never caught up in the race to attract CDM projects. CDM was no longer only a means for Japan to meet its emissions cuts, but was an important means for developing countries such as India and China to access emissions abatement technologies - missing out on these projects was detrimental for India, and was something that India never recovered from, even after IndoJapanese relations improved later in the mid-2000s.

\section{Post-Pokhran II Indo-Japanese relations}

The post-Pokhran II sanctions placed upon India were revoked in October 2001, after India announced a moratorium on tests, and after $9 / 11$ when terrorism took priority in international affairs. ${ }^{\text {xvi }}$ Japan's Prime Minister Mori made a visit to India in August 2000, where together with Prime Minister Vajpayee, declared the Indo-Japanese relationship a 'global partnership'. By 2006, Indo-Japanese relations had improved, with annual Prime Ministerial talks 
resuming, and the issue of a Joint Declaration on Security Cooperation (Panda, 2012). ${ }^{\text {vii }}$ By 2008, the two countries had referred to each other as 'Strategic Global Partners' in the '2008 Joint Statement on the Advancement of Strategic and Global Partnership between Japan and India' (MOFA, 2006). The 2008 'Security Accord' is a framework agreement with 'an action plan on specific measures to advance security cooperation in particular areas, ranging from sea-lane safety and defence collaboration to disaster management and counterterrorism' (Chellaney, 2008). For Japan, this kind of close partnership is only otherwise seen with the United States.

On the economic front, by the mid-2000s, India was viewed to be on par with China as an economic opportunity (Mathur, 2012). At the ASEAN Summit 2009, India also pledged to cut carbon intensity by 25 per cent by 2020 compared to 2005 levels, indicating a proactive stance in GHG mitigation. It would appear that by mid-2000, many of the obstacles impeding Indo-Japanese cooperation were mostly out of the way.

In these circumstances, how does Tokyo view New Delhi? Both India and Japan worry about the rise of China, the string of pearls, and SLOC. Moreover, various other factors such as China's export of nuclear technology to Pakistan and the continuing Indo-Sino border disputes create friction between China and India that should bring India and Japan closer together. Japan has faced its own share of difficulties in its relationship to China, with a surge of anti-Japanese protests in the 2000s and the recent escalation of territorial disputes. These factors, compounded by the issues related to US bases in Okinawa, made Japan distance itself from the United States and look towards Asia. This move is encapsulated in Prime Minister Hatoyama’s (Japan Democratic Party DPJ) ‘Datsu-Bei Nyu-A Policy (2009), literally meaning 'Leave the US and Enter into Asia Policy'. From a strategic standpoint, these same forces conspired to push India and Japan together (Ali, 2007). For example, Abe's visit to 
India in 2007, with a token emphasis on overlapping strategic interests, helped result in an invitation from the host nation to participate in the Malabar 2007 naval exercise. Here, the Indian Navy and Japanese Self-Defence force, together with US, Australian and Singaporean forces participated in non-conventional maritime operations for the first time outside the Indian Ocean, off the Japanese Island of Okinawa. ${ }^{\text {xviii }}$ It would seem that via the China prism, India was looking more attractive as a partner.

The dates for increased CDM activity with India begin in 2005, pick up in 2007 and gradually grow from then on (Japan CDM Platform, 2012). According to Deputy Head of Mission to India, Nishigahiro, relations improved in 2004 (Nishigahiro, 2004). However, the number of Japanese CDMs in India has yet to equal the country's importance in climate change. When we compare Figure 1 and 2, as opposed to the case of Japanese CDMs in India (Figure 2: 5.48 per cent), we see that the total number of CDMs in India (Figure 1: 19.8 per cent) have grown, showing that, when we total all of the Annex I countries, their CDM activities in India reflect the country's importance in the issue. When one considers that China is also a nuclear power, the Japanese response in CDM after Pokhran II appears to have been too strict towards India. This could be explained by the differences in China and India's position on the Comprehensive Nuclear-Test-Ban Treaty. However, the Japanese decision makers' comments above (Hirabayashi and Nishigahiro) indicate the highly intimate nature of Indo-Japanese relations, and suggest that foreign policy-making may have emotional attributes and not be an entirely rational enterprise.

Nuclear issues still play a role in Indo-Japanese relations with Japan again putting pressure on India to sign the CTBT during Prime Minister Hotoyama's visit to India in 2009 (PTI, 2009). Prime Minister Manmohan Singh responded by stating that 'should the US and China ratify the CTBT, a new situation will emerge', placing the onus back on to the US and China. This 
incident indicates that Indo-Japanese relations are heavily influenced by each country's relations with the US and China respectively. Japan is increasingly sensitive to nuclear issues after the Fukushima disaster of November 2011, with the result that nuclear issues now matter even more in Tokyo foreign policy. This is one of the reasons for the delay in the Indo-Japan civilian nuclear cooperation deal, and also explains why Japans CDMs in India have not increased to mirror India's importance in GHGs. ${ }^{\text {xix }}$

\section{Conclusion}

This chapter has sought to understand some of the factors that impact upon Japan's perception of India within the domain of environmental foreign policy. Japan has historically viewed India through the 'prism' of China, and this convenient prism makes India issues both easier for Tokyo to relate to and puts the Indo-Japanese relationship in the context of wider Asia-Pacific relations. The nuclear issue is one that impacts Tokyo in its foreign policy, especially in the context of India. The specific example of climate change and CDM/AIJ projects gives an indication of how much this nuclear lens and the China prism play into Tokyo's decision-making, with Pokhran II as a turning point in Indo-Japanese relations. Several years later, the bilateral relationship is in recovery, but, at least as far as cooperation through the CDM is concerned, there is still some way to go. China and nuclear politics remains a central reference point in Indo-Japan relations. 


\section{Bibliography}

Ali, M. (2007) 'New 'strategic partnership' against China', $B B C$, 3 September, http://news.bbc.co.uk/1/hi/world/south_asia/6968412.stm [accessed 19 June 2014].

Author interview (2009) with MOFA official, London, September, 2009.

Chellaney, B. (2008) ‘Toward Asian power equilibrium’, The Hindu, 1 November, http://www.thehindu.com/todays-paper/tp-opinion/toward-asian-powerequilibrium/article1367350.ece [accessed 18 June 2014].

Dower, J. (1995) 'The Bombed: Hiroshimas and Nagasakis in Japanese Memory,' Diplomatic History, 19, 2, 279-81.

Embassy of Japan in India (2002) 'Japan-India Relations: Outline of Japan’s ODA to India', http://www.in.emb-japan.go.jp/Japan-India-Relations/Japan_ODA_India.html [accessed June 2014].

Fujita, M. and N. Hamaguchi (2006) 'The Coming Age of China plus-One: The Japanese Perspective on East Asian Production Networks', World Bank, http://siteresources.worldbank.org/INTCHIINDGLOECO/Resources/Fujita_Hamaguch i_draft2_ACCEPT_ALL.doc [accessed June 2014].

Ghosh, J. (1998), 'On sanctions and being sanctimonious', Frontline, 6-19 June, http://www.frontline.in/navigation/?type=static\&page=archive [accessed 18 June 2014].

Hance, J. (2013) 'Japan pledges to raise carbon emissions, not cut them', Environmental News Network, 21 November, http://www.enn.com/pollution/article/46706 [accessed 18 June 2014].

Hirabayashi, H. (2002) ‘The Directions of Japan’s Foreign Policy’, in Kesavan, K.V. (ed.) Building a Global Relationship: Fifty Years of Indo-Japanese Relations (New Delhi: Lancer Books). 
Japan CDM Platform (2012) ‘Japanese CDMs by host country’, http://www.kyomecha.org/ [accessed 21 June 2014].

Jaishankar, S. (2000) 'India-Japan relations after Pokhran II', India Seminar, http://www.india-seminar.com/2000/487/487\%20jaishankar.htm [accessed 17 June 2014].

Kobayashi, Y. (2003) 'Navigating Between "Luxury" and "Survival" Emissions: tensions in China's multilateral and bilateral climate change diplomacy' in Harris, P. (ed.), Global Warming and East Asia: The Domestic and International Politics of Climate Change (London and New York: Routledge), 86-108.

Lynas, M. (2009) 'How do I know China wrecked the Copenhagen deal? I was in the room', The Guardian, 22 December, http://www.theguardian.com/environment/2009/dec/22/copenhagen-climate-changemark-lynas [accessed 20 June 2014].

Mathur, A. (2012) 'India-Japan Relations: Drivers, Trends and Prospects', RSIS Monograph (Singapore: S. Rajaratnam School of International Studies), http://www.rsis.edu.sg/publications/monographs/Monograph23.pdf [accessed 12 January 2014].

Mehdudia, S. (2013) 'Several issues hold up civil nuclear deal: Japan', The Hindu, 13 September, http://www.thehindu.com/news/international/south-asia/several-issueshold-up-civil-nuclear-deal-japan/article5122154.ece [accessed 18 June 2014].

Ministry of Foreign Affairs of Japan (2006) 'Joint-Statement Towards Japan-India Strategic and Global Partnership', 15 December, http://www.mofa.go.jp/region/asiapaci/india/pdfs/joint0612.pdf [accessed 12 June 2014].

Ministry of Foreign Affairs of Japan (2013) 'Opinion Survey on the Image of Japan in India', http://www.mofa.go.jp/press/release/press6e_000122.html [accessed 19 June 2014]. 
Morrow, D. and M. Carriere (1999) 'The Economic Impacts of the 1998 Sanctions on India and Pakistan', The Nonproliferation Review, http://cns.miis.edu/npr/pdfs/morrow64.pdf [accessed 19 June 2014].

Nehru, J. (1964) Glimpses of World History: Being Further letters to his Daughter, Written in Prison, and Containing a Rambling Account of History for Young People (Asia Publishing House, Bombay).

Nishigahiro, W. (2004) 'Political and Defence Aspects of India-Japan Relations', CSA Chennai Speech, http://www.csa-chennai.org/Files/indojapan.pdf [accessed 18 June 2014].

Okakura, K. (1904) The Ideals of the East-With Special Reference to the Art of Japan (New York: EP Dutton \& Co.).

Panda, A. (2012) 'India and Japan Come Together', The Diplomat, 1 October, http://thediplomat.com/2012/10/india-and-japan-come-together/ [accessed 19 June 2014].

Pant, H. V. (2010) 'Why an India-Japan nuclear deal is essential', Rediff.com, 27 August, http://news.rediff.com/column/2010/aug/27/why-an-india-japan-nuclear-deal-isessential.htm [accessed 20 June 2014].

PTI (2009) 'Japan wants India to sign CTBT, PM puts onus on US, China', The Times of India, 29 December, http://timesofindia.indiatimes.com/india/Japan-wants-India-tosign-CTBT-PM-puts-onus-on-US-China/articleshow/5391263.cms?referral=PM [accessed 24 June 2014].

Rao, P. V. N. (2009) "Nehru and Non-alignment", Mainstream Weekly, 30 May, http://www.mainstreamweekly.net/article1399.html [accessed June 2014].

Rogers, S. (2012) 'World carbon emissions: the league table of every country', The Guardian, 21 June, 
http://www.theguardian.com/environment/datablog/2012/jun/21/world-carbonemissions-league-table-country [accessed 8 July 2014].

Roy, S. (2013) 'Pokhran test forced Japan Empress to cancel visit in 1998', The Indian Express, 30 November, http://archive.indianexpress.com/news/pokhran-test-forcedjapan-empress-to-cancel-visit-in-1998/1201446/ [accessed 18 June 2014].

Sanger, D. E. (1998) 'U.S. Delays World Bank Loans for India in Response to A-Tests', The New York Times, 27 May, http://www.nytimes.com/1998/05/27/world/us-delays-worldbank-loans-for-india-in-response-to-a-tests.html [accessed June 2014].

Swaminathan, R. (2003) 'Pokhran-II: Five Years Later', South Asia Analysis Group, http://www.southasiaanalysis.org/paper690 [accessed 20 June 2014].

The Japan Forum (2007) 'Japanese Culture and Daily Life: Gifts from Animals to People', http://www.tjf.or.jp/eng/content/japaneseculture/37giftsfromanimals.htm [accessed 19June 2014].

Tenshin, O. (1906) The Book of Tea (London and New York: G P Putnam’s Sons).

Tuke, V. (2011) ‘Japan's Foreign Policy towards India: a Neoclassical Realist Analysis of the Policymaking Process', http://wrap.warwick.ac.uk/49539/1/WRAP THESIS Tuke 2011.pdf [accessed 15 June 2014].

Tuteja, A. (2009) 'Manmohan, Wen stress on harmony, trust', The Tribune, 25 October, http://www.tribuneindia.com/2009/20091025/main1.htm [accessed 20 June 2014].

UNDP (2014) Human Development Index, http://hdr.undp.org/en/statistics/hdi [accessed 8 July 2014].

UNFCCC (2014a) 'Total CDM activities under the UNFCCC by host country', http://cdm.unfccc.int/ [accessed 16 June 2014]. 
UNFCCC (2014b) 'Designated National Authorities', http://cdm.unfccc.int/DNA/index.html [accessed 18 June 2014].

UNSC (1998) 'Press Release SC/6528: Security Council Condemns Nuclear Tests by India and Pakistan', http://www.un.org/News/Press/docs/1998/sc6528.doc.htm [accessed 20 June 2014].

U.S. Energy Information Administration (2012) 'World Oil Transit Chokepoints', http://www.eia.gov/countries/regions-topics.cfm?fips=wotc\&trk=p3 [accessed 19 June 2014].

van Gulik, R.H. (1956) Siddham: An Essay on the History of Sanskrit Studies in China and Japan (New Delhi: International Academy of Indian Culture).

WTO (World Trade Organization) (2013) International Trade Statistics 2013, http://www.wto.org/english/res_e/statis_e/its2013_e/its13_toc_e.htm [accessed 15 June 2014].

\section{Notes}

\footnotetext{
${ }^{\mathrm{i}}$ For details of the importance of Hormuz and Malacca see U.S. Energy Information Administration (2012).
ii Also known as Okakura Tenshin, a Japanese scholar who spread Japanese art and culture and wrote the book The Book of Tea (Tenshin, 1906).

iii Nehru writing in a letter to Indira Gandhi, 'So Japan had won, and she entered the charmed circle of the great Powers... Japan's victory was seen to be due to her adoption of the new industrial methods of the West, and these ideas and methods became more popular all over the East' (Nehru, 1964, p.479).
} 
iv According to the survey, 80 per cent of the surveyed Indians saw India-Japan relations as positive.

${ }^{\vee}$ Both Netaji and Rash Behari Bose spent a period of exile in Japan. Subhas Chandra Bose (1897-1945) was in Japan from 1943-45, and Rash Behari Bose (1886-1945) fled to Japan in 1915, became a Japanese citizen 1923 and spent the rest of his life there. Rash Behari Bose married the daughter of Nakamuraya (a restaurant in Tokyo), and later became known as Nakamuraya's Bose, and introduced 'curry-rice' to Japan.

${ }^{\text {vi }}$ The San Francisco Peace Treaty, or Treaty of Peace with Japan was signed in 1951 and came into force in 1952. The Treaty of Peace between Japan and India was signed on 9 June 1952.

vii Nehru wrote to Tokyo, 'I hope that when the children of India and the children of Japan will grow up, they will serve not only their great countries, but also the cause of peace and cooperation all over Asia and the world. So you must look upon this elephant, Indira by name, as a messenger of affection and goodwill from the children of India' (The Japan Forum, 2007).

viii Many of the ancient Buddhist texts were translated into Japanese from Chinese translations of the Sanskrit originals. Another example is Benzaiten a deity in Japanese Buddhism holding a biwa (Japanese) or pipa (Chinese). Her iconography derives from that of the Hindu deity Sarasvatī, who is traditionally depicted holding a vina : both represent knowledge, music, arts and science.

${ }^{\text {ix }}$ See Dower (1995, p.281) for a discussion on 'Victim Consciousness' (hibakusha ishiki). 
${ }^{\mathrm{x}}$ For further details, refer to the UNFCCC website (UNFCCC, 2014b). For more comprehensive information on CDM in Japan see the Japan CDM Platform website (Japan CDM Platform , 2012), where Ministry of Economic Trade and Industry, NEDO, IGES, JICA, JETRO Japan Bank for International Cooperation, Global Environment Centre Foundation (GEC), JCF, Nippon Export and Investment Insurance, OECC are also involved.

xi The first commitment period of the Kyoto Protocol was 2008-2012, and the second commitment period is 2013-2020.

xii This promise was later withdrawn. Prior to Fukushima, nuclear energy comprised one third of Japan's energy. As a result, the pledge made at Warsaw (COP19 in 2013) was to cut its emissions by 3.8 per cent, based on 2005 levels (Hance, 2013).

xiii After China, USA, India, Russia, and Brazil.

xiv The pilot phase (AIJ) began in 1995, so between 1995 until Pokhran II in 1998, India was the preferred partner.

${ }^{x v}$ Although Japan takes the 'three nuclear principles' and forbids them in the Constitution, the imposition of sanctions are not reflected in legislation.

xvi US lifted sanctions after 9 September 2001 when terrorism became a bigger evil than challenges to the non-proliferation regime, and other countries soon followed the US lead.

xvii India and Japan have annual foreign office consultations at Foreign Secretary level, and also a Security Dialogue between high level defence authorities since 2001. 
xviii Includes anti-piracy operations, search and rescue, humanitarian assistance, disaster relief and counterterrorism.

${ }^{x i x}$ India and Japan are close to a civil nuclear agreement but several things are holding the finalization of the agreement (Mehdudia, 2013). 